|IIIIIIIIIIIIIIIIIIIIIIIIIIIIII

学会賞受賞論文

|IIIIIIIIIIIIIIIIIIIIIIIIIIIIIIII

（業績賞・技術）

\title{
農作物中の残留農薬濃度に関する変動要因の評価
}

\author{
藤田 眞 弘*，飯 島 和 昭 \\ 一般財団法人残留農薬研究所
}

（2013年6月 10日受理）

\section{Evaluation of factors affecting pesticide residue levels in Japanese raw agricultural commodities}

\author{
Masahiro FujıTA* and Kazuaki IıjıмA \\ The Institute of Environmental Toxicology (IET), \\ 4321, Uchimoriya-machi, Joso-shi, Ibaraki 303-0043, Japan
}

Keywords: pesticide residue, variability factor, sampling size, raw agricultural commodity.

\section{は じめに}

物流技術の進歩に伴い, 今日では穀類のみならず，生鮮農 作物についても各国間で大量に流通している. その際, 農作 物の安全管理の指標として重要な役割を担う農薬残留基準值 については, 各国間での不整合が農作物の貿易上の障害とも なりうるため, 国際調和が図られてきている。農薬残留基準 值設定の基礎となる，圈場における農作物栽培を含む作物残 留試験に関わる各種のガイドラインについても国際調和が 図られており ${ }^{1-3)}$, 先頃, 我が国の作物残留試験についても, 試験指針が大幅に改正された ${ }^{4)}$.これにより, 我が国での主 要な農作物に対する作物残留試験については, 試験围場数が 従来の 2 例以上から 6 例以上に増加する. さらに, 従来は可 食部のみとされていた農作物の分析対象部位について, 可食 部に加えて非可食部（仁果類における芯や，メロンにおける 果皮等）も別途分析することが推奨されることとなった。こ れらの試験指針の改訂は, いずれも国際的な食品規格であ

\footnotetext{
* 干 303-0043 茨城県常総市内守谷町 4321

E-mail: fujita@iet.or.jp

(c) 日本農薬学会
}

る $\operatorname{Codex}^{1}{ }^{1}$ や OECD（経済協力開発機構）テストガイドライ ン ${ }^{2)}$ などの国際標準への調和を意図した変更である.

農作物中の残留農薬濃度は, 農作物の種類や栽培方法, 栽 培環境, 農作物の肥大成長, 農薬の物理的化学的特性や分解 性, 農薬製剂の種類, 散布量や使用方法, 圃場からの試料採 取, 分析部位の取り扱いや分析精度など, 多様な変動要因の 影響を受けることが知られている5). しかしながら，この変 動要因については, 必ずしも十分な科学的知見が集積されて いる訳ではなく, 特に, 欧米とは気候や農業慣習の異なる我 が国における体系的な作物残留性に関する検討事例は少ない ため, 各種変動要因間の相対的な影響評価は難しいのが現状 である.

近年, JMPR（国際連合食糧農業機関と世界保健機関： $\mathrm{FAO} / \mathrm{WHO}$ の合同残留農薬専門家会議), 欧州連合及び米国 などでは, 残留農薬のリスク評価を行う際, 一日摂取許容量 （ADI，生涯摂取し続けても健康に影響の出ない一日当たり の最大許容量) に加えて, 一回（一日）単位の摂取による健 康影響を評価するための急性参照用量（ARfD）を設定し, 短期摂取量の推定值と比較した健康リスク判定が進められて いる ${ }^{6-8)}$. 我が国でも，2007年12月から2008年1月にかけ て, 中国産冷凍餃子でメタミドホスに起因する健康被害が発 
生し，農薬の短期暴露量評価に対する関心を集めた。農薬の 短期暴露量評価では，作物 1 個体（または個体の一部）を短 期間に多量に摂取することを想定するため，作物 1 個体単位 での残留量の変動が重要な情報となる，その変動を推定する ための指標として，作物個体ごとの残留量の変動を表す係 数 $V F （$ 個体ごとの残留量の 97.5 パーセンタイルを平均值で 除した值）が用いられており，FAO/WHOにおいては $V F=3$ が採用されている ${ }^{9)}$. 作物個体ごとの残留量の変動について は，海外での検討事例は相当数が蓄積されており ${ }^{10,11)}$ ，それ らが前述の FAO/WHOにおけるVFの根拠ともなっている. しかしながら，我が国における検討事例はほとんどなく，各 種農作物及び農薬での個体別残留量の変動に関する知見が不 足している.

そこで本研究では, リンゴについて戋場間, 分析部位, 個 体間での農薬残留濃度の変動について横断的に調查した。さ らに個体間での農薬残留濃度の変動については, リンゴに 加えて，キャベッ，ブドウ，ブロッコリー，ピーマンの計 5 種農作物を対象として調査した。分析対象農薬としたア セタミプリド及びシペルメトリンは，いずれも日本国内の みならず国際的にも広く使用されており，さまざまな作物 の害虫防除に利用されている。ネオニコチノイド系殺虫剤 のアセタミプリドは比較的極性の農薬例として（水溶解度 $4250 \mathrm{mg} / \mathrm{L}, \log \mathrm{P}_{\text {OW: }}$ 0.80)，一方，合成ピレスロイド系殺虫 剂のシペルメトリンは比較的非極性の農薬例として（水溶解 度 $0.004 \mathrm{mg} / \mathrm{L}, \log \mathrm{P}_{\text {OW: }}$ 6.6), 本研究における調查対象に選 定した ${ }^{12)}$. そのほか，核果類の種子重量の取り扱いが農薬 の残留值評価に与える影響についても知見を得た。本報告て は, 分析值の信頼性確保に資する各種の知見について紹介す る.

\section{1. リンゴにおける圑場間，分析部位及び個体別の 3 種 変動要因が残留濃度に与える影響 ${ }^{13)}$}

国内 8 圃場で栽培したリンゴについてシペルメトリンの残 留分析を行い，戋場間での残留濃度の变動を比較した。その 際，リンゴ果実の可食部，非可食部の分別分析と，それらを 区別しない果実全体での分析を行い，分析対象部位による 残留濃度の差異に関する知見を得た。さらに，2固場におい てはリンゴ 130 試料の個体別の残留性を調查した。リンゴ栽 培は，作物残留試験ガイドライン ${ }^{4)}$ に準拠した慣行的な管理 を行い，分析試料を調製した。薬剤処理は，アグロスリン水 和剂（シペルメトリン $6 \%$ 含有）の 1000 倍希釈液を，動力噴 霧機あるいは背負い式バッテリー噴霧器を用いて $10 \mathrm{a}$ 当たり 400〜 500 L となるように7日間隔で 3 回散布し，最終散布 14 日後に試料を採取した。

8 糐場で採取したリンゴ試料の可食部（花落ち，芯及び 果梗の基部を除いた 10 個体分の均一化試料の分析值）にお けるシペルメトリンの平均残留値土標準偏差（SD）は 0.28 $\pm 0.08 \mathrm{mg} / \mathrm{kg}$ であり，それらの最大変動幅は2.3倍（最低〜 最高值 $0.18 \sim 0.42 \mathrm{mg} / \mathrm{kg}$ ) であった。 また, リンゴ全果実を 分析対象とした場合の 8 戋場間での平均残留値 $\pm 0.08 \mathrm{mg} / \mathrm{kg}$ であり, それらの最大変動幅は 2.3 倍（0.16〜 $0.36 \mathrm{mg} / \mathrm{kg}$ ) であった. さらに, 可食部及び非可食部の部位 別分析值から得た各残留值と各部位の重量比に基づき, 計 算値として求めた全果実の 8 圃場間での平均残留值 \pm S.D.は $0.31 \pm 0.10 \mathrm{mg} / \mathrm{kg}$ であり, それらの最大変動幅は2.3倍 $(0.20 \sim 0.46 \mathrm{mg} / \mathrm{kg})$ であった.

8 戋場間での最大変動幅は, 分析対象部位を可食部とした 場合, 全果実とした場合, 可食部と非可食部を部位別分析し た場合のいずれにおいても 2.3 倍で, 分析部位の違いが与え る影響は認められなかった。リンゴの分析部位は，海外では 「果実全体」であるが，国内では「花落ち，芯及び果梗の基 部を除去したもの (可食部)」と規定されており, 同時に非 可食部の分別分析が推奨されている. 国際的な標準分析部位 である「果実全体」と，現行国内評価対象である「可食部」 では，残留濃度は異なることも予想されたが，本調査におい ては，残留值に明確な差異は認められなかった。しかしなが ら, 全体的に非可食部の残留濃度は可食部よりも高い濃度を 示していた（最大 4.5 倍). その原因としては, 散布農薬の 果梗基部の窪みでの残留性が高いことが推察された。

岩手及び福島の 2 围場で収穫したリンゴ中のシペルメトリ ンの個体別残留濃度の平均值は, それぞれ 0.21 及び $0.24 \mathrm{mg} /$ $\mathrm{kg}$ であり, その平均值と中央值は一致していた，岩手及び 福島の個体別の残留濃度は, それぞれ $0.04 \sim 0.43 \mathrm{mg} / \mathrm{kg}$ 及び $0.04 \sim 0.46 \mathrm{mg} / \mathrm{kg}$ の範囲であり, 両戋場試料ともに最大変動 幅は約 10 倍であった．両戋場試料での個体別残留濃度の分 布パターンは近似しており，いずれもおおむ称正規分布を示 した。 そして, 岩手及び福島の個体別の残留データから算出

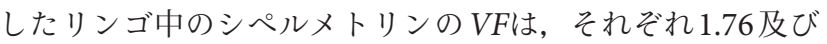
1.75 で同等であった。

本調査は, 1 農作物の 1 農薬における限定的な試験である ため, 調査対象作物及び農薬の特性を反映した限定的な知見 であるが，その結果においては，圃場内個体間の差が，残留 濃度值に関与する最も大きな変動要因であった．個体間の残 留濃度の変動と比較して, 8 圃場間での残留濃度の差や, 分 析対象部位を可食部とした場合と果実全体とした場合での残 留濃度の差は小さかった。围場内個体間の残留濃度の变動 は, 一定の試料量及び個体数（本調査では 10 個）の確保に より抑制され，圃場の代表值として妥当な結果が得られるこ とが確認された。

\section{2. 各種農作物における個体別変動の比較 ${ }^{14,15)}$}

前章でのリンゴにおける3種変動要因の横断的な比較調查 において，最も大きな影響を与えたと判断した個体別残留值 の変動について, シペルメトリンよりも極性の高いアセタミ 
プリドを分析対象農薬に加えて, 各種農作物における残留性 を調査した。ピーマン固場では，アグロスリン水和剤 2000 倍希釈液を $10 \mathrm{a}$ 当たり $250 \mathrm{~L}$ となるよう 7 日間隔で 2 回散布 し，最終散布の翌日に試料を採取した．ブロッコリー圑場で は，モスピラン水溶剤（アセタミプリド $20 \%$ 含有）の 2000 倍希釈液を $10 \mathrm{a}$ 当たり $250 \mathrm{~L}$ となるように 7 日間隔で 3 回散 布し，最終散布 14 日後に試料を採取した。キャベツ固場で は，アグロスリン水和剤とモスピラン水溶剤の1000倍混合 希釈液を 10 a 当たり 213〜292 L となるように7日間隔で 3 回 散布し, 最終散布 7 日後に試料を採取した。ブドウ園では, アグロスリン水和剤 1000 倍希釈液を $10 \mathrm{a}$ 当たり $300 \mathrm{~L}$ となる ように7日間隔で 5 回散布し, 最終散布 7 日後に試料を採取 した.ブドウ園における 5 回の農薬散布の内, 中間時点の 3 回分については, アグロスリン水和剤とモスピラン水溶剤 2000 倍混合希釈液とした，従って，ブドウ中のアセタミプ リドについては, 最終散布 14 日後の収穫となる。

ピーマン，ブロッコリー及びブドウ中のアセタミプリドま たはシペルメトリンの個体別残留濃度の平均值はおおむね中 央值と一致しており，それらの個体別残留濃度の分布パター ンはおおむね正規分布を示した。これら 3 作物での個体別残 留濃度の傾向は, 前述したリンゴでの調査結果と同様であっ た。一方，キャベッ中のアセタミプリド及びシペルメトリン の個体別残留濃度の平均值（それぞれ0.129及び0.066 mg/ $\mathrm{kg}$ ）は，それらの中央值（それぞれ 0.116 及び $0.056 \mathrm{mg} / \mathrm{kg}$ ) よりも高く，いずれも正規分布には従わず低濃度域に偏った 残留分布パターンを示した。

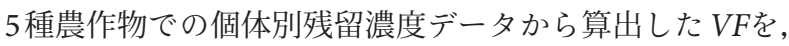
各農作物の平均個体重量順に整理して Fig. 1に示す. 本調査 において個体別残留值の変動が最も小さかったのはピーマ ン中のシペルメトリンで，その最大変動幅は 4 倍（最低〜最

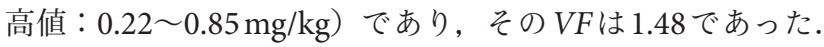
逆に, 個体別残留值の変動が最も大きかったのはキャベツ中 のシペルメトリンで，その最大変動幅は53倍以上（最低〜

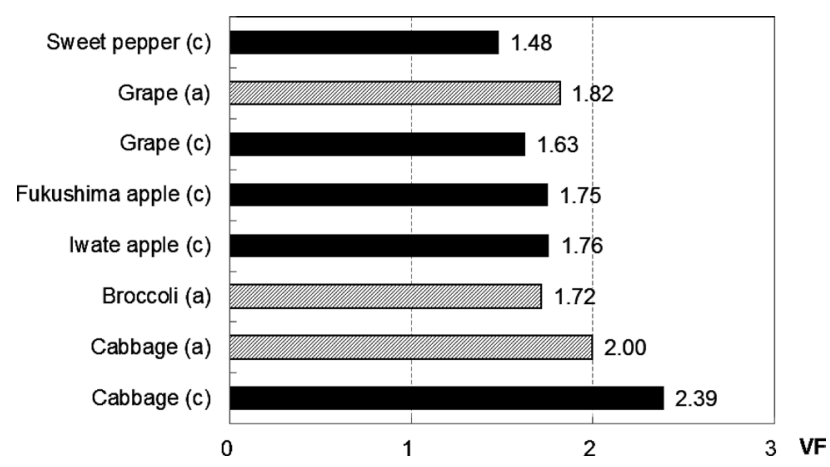

Fig. 1. Variability factor $(V F$, the 97.5 th percentile of the residue levels in the sample divided by the average residue levels in the lot) of acetamiprid (a) and cypermethrin (c) in 5 kinds of raw agricultural commodities.

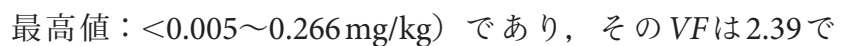
あった. 各種農作物での VFと平均個体重量との間には, 有 意な相関性があり $\left(R^{2}=0.758\right)$, 農作物の重量が大きくなる に従い個体別の残留濃度の変動が大きくなる傾向が認められ た。

本調査で得られた VFは，マンゴーならびにレタスにおけ るシペルメトリンの $V F^{\text {報告值 }}{ }^{11)} 1.73 \sim 2.31$ や, FAO/IAEA (International Atomic Energy Agency) プロジェクト報告 ${ }^{9)}$ の $V F$ (小粒果実 2.82 , 葉菜類 2.14 , 大型果実 2.45 , 総平均 2.47）と比較すると, 同等もしくは比較的小さな值であっ た.この原因は, 国内圃場は諸外国と比較して小規模なため 農薬製剂が精密に散布されるため, 農作物への農薬の付着量 が比較的均一となるものと推察された.

混用散布したブドウにおけるアセタミプリドとシペルメ トリンの個体別残留值を比較した結果，ブドウにおいては両 農薬の残留值間に有意な相関性が認められた $\left(R^{2}=0.8415\right)$. 一方, キャベツにおけるアセタミプリドとシペルメトリンの 個体別残留值間では相関性が低く，アセタミプリドの残留值 に対して, シペルメトリンの残留值がやや高くなる傾向が伺 えた。なお，有意な相関性が認められたブドウについては， アセタミプリドとシペルメトリン製剤の散布回数（それぞれ 3 回及び 5 回の散布, シペルメトリンの 2,3 及び 4 回目の散布 においてアセタミプリドを混用散布）と各剂最終散布から収 穫までの日数が異なるが, 個体別の残留值に相関関係が認め られなかったキャベツにおける両農薬製剤の処理条件は同一 であった。

本研究においては, キャベツにおける個体別残留值の変 動が比較的大きく，低濃度域に偏った残留分布パターンを 示し,アセタミプリドとシペルメトリンでの残留傾向にも違 いが認められた。そこで，キャベツにおける特異な残留傾向

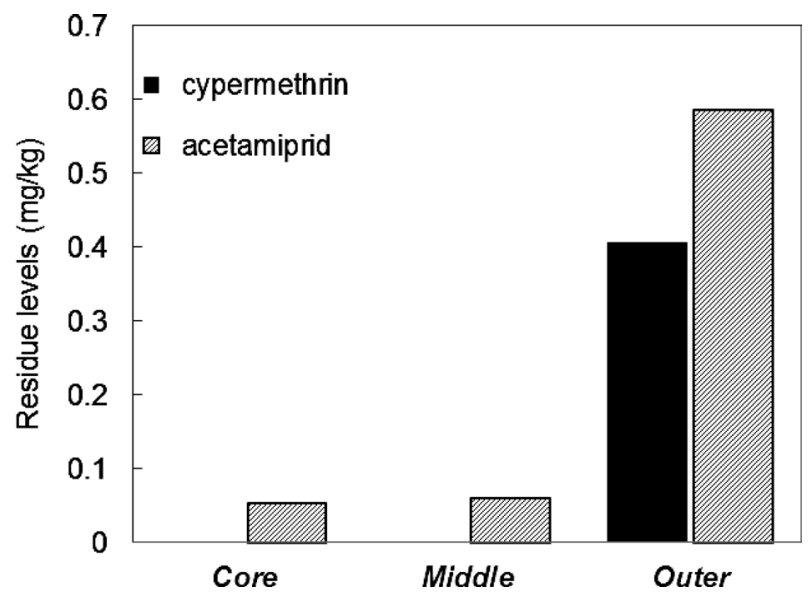

Fig. 2. Distribution of the residue levels of acetamiprid and cypermethrin in cabbage. Portions were divided into three equal portions on weight basis as core side (Core), middle position (Middle) and outer side (Outer) leaves. 


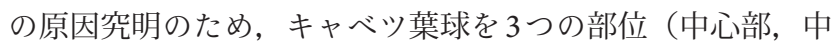
間，外側）に分別した残留量を調査した。その結果，アセタ ミプリド及びシペルメトリンのいずれにおいても, 残留農薬 の多くがキャベツ葉球の外側に局在していた (Fig. 2参照). 比較的極性で浸透移行性を有するアセタミプリドについて は, キャベツ葉球の中心及び中間部分で，それぞれ $8 \%$ 及び 9\%相当量の残留が認められたが, 比較的非極性なシペルメ トリンについては, キャベッ葉球の中心及び中間部分での残 留は認められなかった。この調査結果から，キャベッにおい ては, 結球葉菜類に特有な外葉の取り扱いが, 他種作物とは 異なる残留濃度の変動要因であることを確認した。 なお, 本 研究においては, リンゴ試料における可食部と非可食部の部 位別分析を除き, 変動要因となりうる分析試料の縮分操作は 行わなかった。

\section{3. 試料量（数）による分析值の変動に関する影響 ${ }^{15)}$}

5 種農作物での個体別残留データを用いて, 試料量（数） が残留濃度に与える影響を試算した。 その解析は, 各農作物 での個体別残留值に乱数を割付け，その乱数に基づき順次， 各試料数（ $n=2,4,8,16,32,64)$ における平均残留濃度を母 集団と同数となるように試算し, 各平均残留濃度の標準偏 差パーセント（RSD）を, 各解析条件における変動指標とし た。当該数值処理は計 5 回行い，その平均值を算出した。ま た, 各試料数における総試料重量（平均個体試料重量 $\times n$ ) を試料量と仮定して，これと RSDとの相関性を解析した。

経験的に知られているとおり, 本解析結果においても試料 量が大きくなるに従い残留濃度の変動は明瞭に低減した。な お，本研究に供試した各作物の個体重量はおおむね正規分布 に従っており，個体別残留值との間に相関性が無いことを確 認した。各種農作物における RSD試算值は, 試料量が大き くなるにつれて順次低下し，その程度は母集団の $V F か ゙$ 最も 小さかったピーマン中シペルメトリンが最も小さく，逆に， 母集団の $V F$ 最も大きかったキャベツ中シペルメトリンが 最も大きかった。 そして，解析結果に基づく試料量 $(x)$ と 残留濃度の変動（ $y:$ RSD）との関係は, いずれの試料にお
いても累乗近似曲線で良好な相関性を示した $(y=\mathrm{a} \times x+\mathrm{b}$, $\left.R^{2}>0.86\right)$.

調査対象とする試料量（試料数）をどの程度確保すること が望ましいかは, 分析目的によるところが大きいが, 作物 残留試験については各種試験指針において規定されている. 農水省ならびにOECDテストガイドラインの作物残留試験 における本研究の調査対象農作物に対する試料量を Table 1 に示す。そして, 前述した試料量とRSDとの関係式を用い

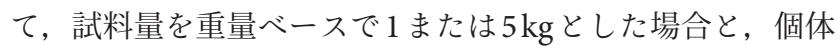
数ベースで 5 または 12 個とした場合の計 4 パターンでの各種 農作物における残留値の予測変動を Fig. 3に示す。これらの 図は, 同一試料量とした場合の各種農作物の残留值の変動 は, 平均個体重量に応じて大きくなることを示す．例えば， 平均個体重量が $1.33 \mathrm{~kg}$ と最も大きかったキャベツにおいて は, 試料量 $5 \mathrm{~kg}$ が 4 個体に満たないため, シペルメトリンで の RSD試算值は $32 \%$ となり, 残留濃度の変動が大きくなる. 一方, 同一試料数とした場合では, 各種農作物での変動が 平準化されることがFig. 3から確認できる. 例えば, 試料数 を 5 及び 12 個体とした場合の RSD試算值は, それぞれ最大 28\%（ブドウ中のアセタミプリド）及び15\%（キャベッ中の シペルメトリン）であった。ただし，大型農作物の 12 個体 の総試料量は相応の試料量となるため, 試料採取, 移送, 均 一化試料の調製などの作業負担が大きくなることに留意する 必要がある。例えば, 本調査におけるキャベッ12個体の総 重量は約 $16 \mathrm{~kg}$ となる.

本解析により，母集団を代表する真值を得るためには，一 定量以上の試料量（数）を確保することの重要性が示され た。したがって, 農薬残留基準值設定の基礎となる作物残留 試験において固場を代表する残留值を求める場合や，ロット 単位での残留基準值の判定においては, 各種規定に示される 試料量を確保することが重要となる。しかしながら, 調査目 的によっては，試料を十分量確保することが困難な場合も多 く，そのような場合には本調査データを活用して残留值の変 動を推察することも可能である.さらに本研究では, 予備試 料での確認分析を含めた残留基準值付近での誤判定の確率を

Table 1. Regulatory sampling size and measured sample weight for each testing raw agricultural commodity

\begin{tabular}{lllr}
\hline & $J_{\text {-MAFF }}^{a)}$ & OECD $^{a)}$ & Sample weight $^{b)}$ \\
Sweet pepper & 5 plants, $1 \mathrm{~kg}$ & 24 plants, $2 \mathrm{~kg}$ & $31 \mathrm{~g}$ \\
Grape & 5 plants, $1 \mathrm{~kg}$ & 12 bunches, $1 \mathrm{~kg}$ & $155 \mathrm{~g}$ \\
Apple & 5 plants, $2 \mathrm{~kg}$ & 12 plants, $2 \mathrm{~kg}$ & $421 \mathrm{~g}$ \\
Broccoli & 5 plants, $2 \mathrm{~kg}$ & 12 plants, $1 \mathrm{~kg}$ & $523 \mathrm{~g}$ \\
Cabbage & 5 plants, $5 \mathrm{~kg}$ & 12 plants & $1330 \mathrm{~g}$
\end{tabular}

\footnotetext{
a) The regulatory sampling size for each raw agricultural commodity according to the test guidelines for crop field trials by the Japanese Ministry of Agriculture, Forestry and Fisheries $(J-\mathrm{MAFF})^{4)}$ and the Organization for Economic Cooperation and Development $(\mathrm{OECD}){ }^{2)}{ }^{b)}$ Measured sample weights in this study.
} 

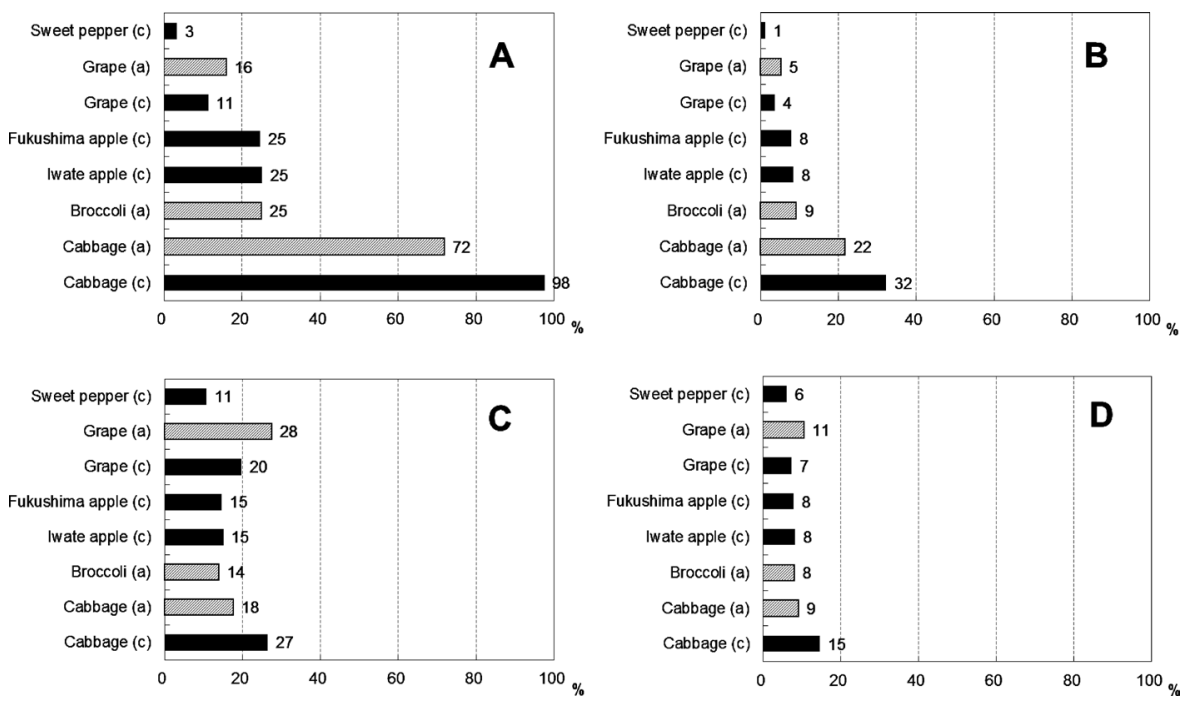

Fig. 3. Estimated uncertainty in pesticide residue levels of acetamiprid (a) and cypermethrin (c) based on the sampling size as various weights (A: $1 \mathrm{~kg}, \mathrm{~B}: 5 \mathrm{~kg}$ ) and commodity unit numbers (C: 5, D: 12).

試算し，試料量確保の重要性を確認した ${ }^{14)}$.

\section{4. 核果類の種子の重量が農薬の 残留値評価に与える影響 ${ }^{16)}$}

作物残留性試験用の分析試料として提供されたモモ，ウ メ, オウトウ, スモモ, ネクタリンの核果作物について, 種 子とその他の果実部位別の重量を調査し, 可食部での農薬 の残留値（種子を含まない）を全果実での農薬の残留値（種 子を含む）に換算するための係数（可食部重量/全果の総重 量）を算出した。その結果, 国内慣行による種子を除いた核 果作物の農薬の残留值を, 国際標準に従った種子を含む果実 全体の農薬の残留值に換算するために乗じる係数は 0.88 (ウ メ）から 0.96 (スモモ）の範囲であり，オウトウやウメなど の小粒果実類の方が農薬の残留值を全果実換算した場合の影 響が大きかった，核果類に代表される硬質の種子を有する果 物については, 現行国内慣行による農薬の残留值を, 国際標 準（種子を含む果実全体）に変更した場合には，わずかに低 い值となることを既存データ解析により確認した。

\section{おわりに}

本研究では, 围場間, 分析部位, 個体間での農薬残留濃度 の変動要因の一端を明らかにした。しかしながら, 各種農薬 及び農作物における多様な使用条件での農薬の残留性を予測 するのは難しいのか現状である. 我々は, 今後も各種農薬及 び農作物での作物残留性を調査し, 農薬残留濃度の多様な変 動要因を明らかにしたいと考えている.

本研究の知見は, 残留農薬の人への健康影響評価の基本で ある慢性影響に基づくロット単位での農作物中の残留農薬濃 度を正確に把握するために有益な知見であるとともに，近
年, 整備が進められている急性影響に基づく個体別の農作物 中の残留農薬濃度でのリスク評価にも有益である。また本研 究成果は, 国内のみならず海外での既存残留農薬データと, 現行国際標準に沿った最新の残留農薬データ間の整合性を図 るために有効な知見である。これらの知見が, 農薬残留の適 切なリスク評価や, 農業現場における農薬の安全使用の推進 に活用されることを期待したい。

\section{謝辞}

本研究は, 農林水産省の「農薬的資材安全性評価情報整備 事業」の一環として実施された。当該事業の専門委員からの ご助言に感謝します。また，試料の調製にご協力頂いた一般 社団法人日本植物防疫協会ならびに戋場の関係者の皆様に感 謝します．本研究をご指導頂いた佐藤清博士ならびに小田中 芳次博士 (現公益財団法人日本植物調節剂研究協会), 本研 究の遂行にご協力頂いた一般財団法人残留農薬研究所化学部 の皆様に感謝します.

\section{引用 文 献}

1) "Submission and Evaluation of Pesticide Residues Data for The Estimation of Maximum Residue Levels in Food and Feed"; FAO Plant Production and Protection Paper 197, Food and Agriculture Organization of the United Nations, Rome (2009).

2) "OECD Guideline for the Testing of Chemicals 509; Crop Field Trial," Organization for Economic Cooperation and Development, Paris (2009).

3) O. E. C. D. Maximum Residue Limit Calculator: The Organization for Economic Co-operation and Development, Paris, France (2011), http://www.oecd.org/document/8/0,3746, 
en_2649_34383_47259976_1_1_1_1,00.html (accessed May $28,2011)$.

4）農林水産省農産園芸局長通知，12農産8147号，2000年11月 24 日付け（最終改定2011年4月1日）。

5) Á. Ámbrus, A. Zentai, J. Sali and I. Ficzere: Accredit. Qual. Assur. 16, 3-11 (2011).

6) R. Solecki, L. Davies, V. Dellarco, I. Dewhurst, M. van Raaij and A. Tritscher: Food Chem. Toxicol. 43, 1569-1593 (2005).

7) D. Hamilton, Á. Ámbrus, R. Dieterle, A. Felsot, C. Harris, B. Petersen, K. Racke, S. Wong, R. Gonzalez, K. Tanaka, M. Earl, G. Roberts and R. Bhula: Pest Manag. Sci. 60, 311-339 (2004).

8) "A Review of the Reference Dose and Reference Concentration Processes," EPA Final Report, Risk Assessment Forum, U.S. Environmental Protection Agency (2002).

9) "Estimation of Variability Factor for the Use for Calculation of Short Term Intake," Pesticide Residues in Food REPORT 2005, FAO Plant Production and Protection Paper 183: Chapter 2.8, World Health Organization, Food and Agriculture Organization of the United Nations, Rome (2005).

10) "Opinion of the Scientific Panel on Plant Health, Plant Protection Products and their Residues on a Request from Commission Related to the Appropriate Variability Factor(s) to be Used for Acute Dietary Exposure Assessment of Pesticide Residues in Fruit and Vegetables," EFSA J. 177, 1-61 (2005).

11) Á. Ámbrus: Pest Manag. Sci. 62, 693-714 (2006).

12) C. D. S. Tomlin (eds.): "The Pesticide Manual, Fourteenth Edition," British Crop Production Council, Hampshire, 2006.
13) 藤田眞弘, 矢島智成, 浜野浩子, 逆井美智子, 飯島和昭, 佐藤 清：農薬誌37, 183-189 (2012).

14) M. Fujita, T. Yajima, K. Iijima and K. Sato: J. Agric. Food Chem. 60, 4457-4464 (2012).

15) M. Fujita, T. Yajima, K. Iijima and K. Sato: J. Agric. Food Chem. 60, 1516-1521 (2012).

16) K. Iijima, T. Yajima, M. Nagata, S. Sugimoto, M. Fujita, K. Sato and Y. Kato: J. Pestic. Sci. 36, 492-494 (2011).

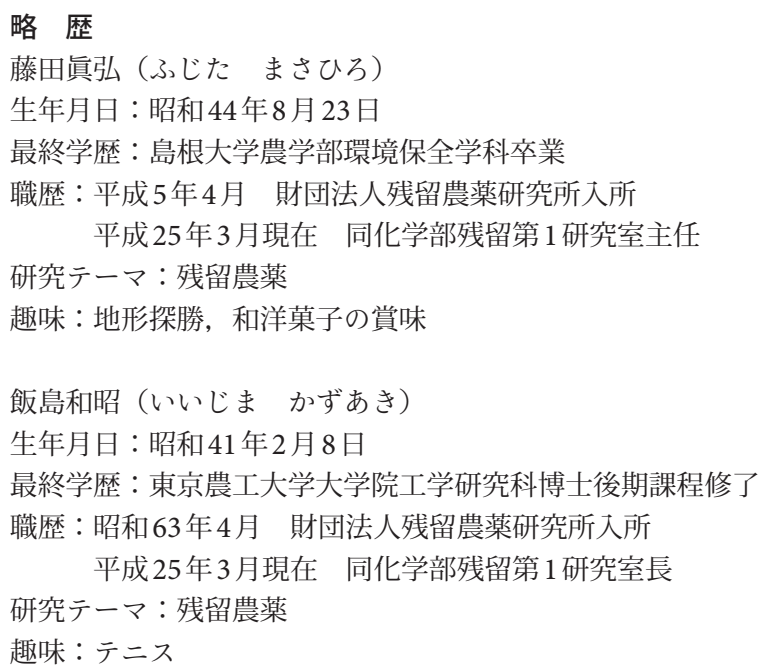

